\title{
IMPORTANT PROVISIONS FOR THE DEVELOPMENT OF AGRICULTURE OF UKRAINE
}

\author{
Svetlana KHALATUR ${ }^{1}$ \\ Dnipropetrovsk State Agrarian and Economic University, Ukraine
}

\begin{abstract}
The aim of the work is to study the state of development of agriculture in Ukraine. The indicators of production and yield of the main agricultural crops and production of the main types of livestock products are analysed. The main directions of the development of agriculture are determined taking into account the transformations in the agrarian sphere. Solutions of the problem of investment support for the development of agriculture are investigated. The main factors that restrain the growth of the industry and inhibit the development of agricultural enterprises are given. Based on the results of the analysis, the main problems that the sector has faced recently are identified and the issues that require priority solutions are listed. The subject is the theoretical and methodological foundations and practical recommendations on the search for reserves for the development of the agricultural sector. Methodology. The study is based on a comparison of data from 2009 to 2015, using statistical compilations. The results of the research showed that the livestock sector begins to decline in Ukraine and this means that in the further such situation, it is possible to lose the opportunity not only to export livestock products abroad but also to meet the domestic needs of the country's population. The state of agriculture in Ukraine is considered. The results showed that the main reserves of the development of agriculture in Ukraine are the state regulation, assessment of the attractiveness of the investment climate, the use of environmentally safe technologies, the use of modern technologies and mechanisms for the economic stimulation of production and processing of agricultural products. Value/originality. The data obtained during the research years of the main reserves of agricultural development in Ukraine are able to provide a better understanding of the state of the agricultural sector in the conditions of the economic downturn in general and in Lithuania in particular.
\end{abstract}

Key words: agriculture, agro-industrial complex (AIC), investment climate, productivity, crop production, animal husbandry, environment-friendly technology, economy, agricultural sector.

\section{JEL Classification: Q13, L1}

\section{Introduction}

Ukraine is a country with strong agricultural potential and vast prospects of agriculture. It has favourable climatic conditions and quality of land resources, the presence of which indicates the possibility of effective development of agricultural production.

Agriculture today is among the most promising sectors of the Ukrainian economy. Ukraine is gradually becoming a serious player in global agricultural and food markets, occupying leading positions in the trading and processing of grains exporting significant amounts of vegetable oil and dairy products. However, insufficient and inadequate legal framework and the lack of real funding agriculture Ukraine (despite the formal existence of state support programs) hinder the development of enterprises of the agricultural sector.

Analysis of recent research and publications. The study prospects for agricultural development has long been involved Ukrainian scientists, including
A.N. Borodin, I.R. Zalutsky, V.K. Zbarskyy, U.Y. Luzan, V.J. Mesel-Veselyak, B.I. Paskhaver, A.J. Picos, I.V. Prokop, P.T. Sabluk, M.P. Talavyrya, N.M. Fedorov, V.G. Andreychuk, V. Yurchushun, P.S. Berezovsky, N.V. Vyshyvaniuk, O.N. Onishchenko, G.V. Cherevko, L.M. Hazuda, I.V. Svynous and others.

Unsolved aspects of the problem. Despite a thorough analysis, carried out in the writings of these authors, the problem of effective agricultural development requires further theoretical and methodological research and practical developments.

The purpose of the article. The main purpose is to analyse the current state of agricultural development, identification of key provisions of agricultural development in Ukraine.

Presenting the main material. Agriculture of Ukraine (APC) is a leading inter-sectoral territorial and industrial structure of the economy of Ukraine, producing $2 / 5$ of GDP and concentrates $1 / 3$ ofall employees in the economy. This is a complete, integrated system of large-scale,

Corresponding author:

${ }^{1}$ Department of Finance and Banking, Dnipropetrovsk State Agrarian and Economic University.

E-mail: halatyr@i.ua 
complex structure and territorial organization. The role of agribusiness in the economy cannot be overestimated because of its level of development areas and sustainable operation depends on security needs of the population in the major types of food according to physiological norms of consumption, welfare, and the amount of supply to the market. However, the pace of economic development of agriculture insufficient because it does not solve important social, economic, and social needs.

The current state of agriculture of Ukraine is characterized by a deep crisis caused by factors as general economic character and shortcomings agricultural policy. The essence of the crisis is the shortage and poor quality of food, stagnation, and the high cost of production, a marked decrease in food self-sufficiency of the population and its regions, the growth of imports of basic foodstuffs in the food balance.

\section{The current state analysis of agriculture of Ukraine:}

Among the reasons for this situation, there can be distinguished (Pavlenko, 2015):

1. The lack of land prices and taking into account its agricultural production.

2. The inadequacy of means and ends in agricultural development - deformation structures complex.

3. The disparity in prices for agricultural and industrial products.

4. False strategy investments.

5. Ignoring the experience of developed foreign countries.

6. Too poor logistics in the processing industries, much of the park is worn and outdated, full immunity to the field of scientific-technical progress.
7. Inefficiently used production capacity of the complex, its potential, slowly increasing core performance agriculture - crops and livestock. Production of significant amounts of agricultural products, including livestock, moved to peasant households, which does not contribute to the quality and competitiveness, the use of new technologies, and improving resource availability.

\section{Livestock as an important reserve of agricultural development}

Let us analyse the dynamics of livestock and poultry in Ukraine for 2009-2015 years based on Table 1 .

Analysing the data in Table 1, we can conclude that the cattle population has declined by more than $14 \%$ in all types of households Ukraine. There was a decrease in the number of pigs, sheep, and goats more than $10 \%$, only agricultural enterprises increased the number of pigs and poultry by $11.5 \%$. Overall livestock dynamics in all types of households for years has studied the negative trend. This shows that the livestock industry like agriculture in Ukraine gradually declines.

Livestock industry in Ukraine began to decline, which means that in the future this regard thereto Ukraine, with its huge potential not only lose the opportunity to export animal products abroad but also provide domestic needs of the population.

Let us analyse the dynamics of livestock and poultry productivity in agricultural enterprises for the years 2009-2015 based on Table 2 .

Analysing the data in Table 2, it can be concluded that the productivity of cattle and pigs increased by about $4 \%$, average annual milk yield per cow

Table 1

Dynamics of livestock and poultry in Ukraine for 2009-2015 years, million heads

\begin{tabular}{|c|c|c|c|c|c|c|c|c|}
\hline Name & 2009 & 2010 & 2011 & 2012 & 2013 & 2014 & 2015 & Change, $\%$ \\
\hline \multicolumn{9}{|c|}{ Farms of all categories } \\
\hline Cattle & 4827 & 4494 & 4426 & 4646 & 4534 & 3884 & 3750 & 77,69 \\
\hline including cows & 2737 & 2631 & 2582 & 2554 & 2509 & 2263 & 2167 & 79,17 \\
\hline Pigs & 7577 & 7960 & 7373 & 7577 & 7922 & 7351 & 7079 & 93,43 \\
\hline Sheep and goats & 1833 & 1732 & 1739 & 1738 & 1735 & 1371 & 1325 & 72,29 \\
\hline Poultry & 191 & 204 & 201 & 214 & 230 & 213 & 204 & 106,58 \\
\hline \multicolumn{9}{|c|}{ Agriculture } \\
\hline Cattle & 1627 & 1526 & 1511 & 1507 & 1438 & 1310 & 1270 & 78,06 \\
\hline including cows & 605 & 589 & 584 & 575 & 565 & 529 & 505 & 83,47 \\
\hline Pigs & 3308 & 3625 & 3319 & 3557 & 3879 & 3733 & 3704 & 111,97 \\
\hline Sheep and goats & 316 & 299 & 290 & 265 & 248 & 205 & 187 & 59,18 \\
\hline Poultry & 100 & 111 & 106 & 118 & 132 & 122 & 112 & 111,55 \\
\hline \multicolumn{9}{|c|}{ Households } \\
\hline Cattle & 3200 & 2968 & 2915 & 3139 & 3096 & 2574 & 2480 & 77,50 \\
\hline including cows & 2132 & 2042 & 1998 & 1979 & 1944 & 1734 & 1662 & 77,95 \\
\hline Pigs & 4269 & 4335 & 4054 & 4020 & 4043 & 3618 & 3375 & 79,06 \\
\hline Sheep and goats & 1517 & 1433 & 1449 & 1473 & 1487 & 1166 & 1138 & 75,02 \\
\hline Poultry & 91 & 93 & 95 & 96 & 98 & 91 & 92 & 101,10 \\
\hline
\end{tabular}


Table 2

Dynamics of productivity of livestock and poultry in farms for the years 2019-2015, kg

\begin{tabular}{|c|c|c|c|c|c|c|c|c|}
\hline Indicator & 2009 & 2010 & 2011 & 2012 & 2013 & 2014 & 2015 & Change, $\%$ \\
\hline \multicolumn{9}{|c|}{ The average weight per head of cattle, which is sold to processors, $\mathrm{kg}$} \\
\hline Cattle & 423,00 & 414,00 & 424,00 & 439,00 & 438,00 & 427,00 & 439,00 & 103,78 \\
\hline Pigs & 108,00 & 108,00 & 108,00 & 108,00 & 109,00 & 110,00 & 112,00 & 103,70 \\
\hline Average annual milk yield per cow, $\mathrm{kg}$ & 3893,00 & 3975,00 & 4109,00 & 4676,00 & 4827,00 & 5027,00 & 5352,00 & 137,48 \\
\hline Average annual wool clip from a sheep, $\mathrm{kg}$ & 2,80 & 2,30 & 2,20 & 1,90 & 1,80 & 1,60 & 1,70 & 60,71 \\
\hline $\begin{array}{l}\text { The average annual egg production of } \\
\text { laying hens, units }\end{array}$ & 280,00 & 281,00 & 286,00 & 293,00 & 289,00 & 276,00 & 252,00 & 90,00 \\
\hline
\end{tabular}

increased by $37.48 \%$. The performance of sheep, goats, and poultry decreased because the average annual wool clip from a sheep decreased by $39.29 \%$ and the average annual egg production of laying hens decreased by $10 \%$.

\section{Plant growing as an important reserve of agricultural development}

One should consider the fact that the main indicator of the relative productive economic status and development of crop production and agricultural productivity is generally crops. An analysis of the dynamics of productivity of major crops for the years 2009-2015 is done based on Table 3.
Given the data from Table 3, we can conclude that the yield of major crops studied for years had tended to increase overall productivity increased by more than $15 \%$ in all cultures. Regarding the acreage of major crops, in the last 20 years, they have also undergone significant changes.

Given the data from Table 4, we can conclude that the area of sown crops such as maize, soybean, sunflower, and sugar beet tends to increase because the culture is in great demand and brings high returns in respect to other cultures - a trend decline. Square pure vapour in 2015 compared to 2009 decreased by almost $60 \%$.

However, note that often argued on the need to reduce arable land in Ukraine, because the reduction of the cultivated area can be regarded as positive. But still

Table 3

Dynamics of productivity of major crops for 2009-2015 years c/ha

\begin{tabular}{|c|c|c|c|c|c|c|c|c|}
\hline Indicator & 2009 & 2010 & 2011 & 2012 & 2013 & 2014 & 2015 & Change, $\%$ \\
\hline Cereals & 29,80 & 26,90 & 37,00 & 31,20 & 39,90 & 43,70 & 41,10 & 137,91 \\
\hline \multicolumn{9}{|c|}{ Including } \\
\hline Wheat & 30,90 & 26,80 & 33,50 & 28,00 & 33,90 & 40,10 & 38,80 & 125,56 \\
\hline Rye & 20,70 & 16,70 & 20,70 & 22,70 & 22,80 & 25,80 & 25,90 & 125,12 \\
\hline Barley & 23,70 & 19,70 & 24,70 & 21,10 & 23,40 & 30,10 & 29,50 & 124,47 \\
\hline Oat & 17,60 & 14,80 & 18,10 & 20,90 & 19,40 & 25,10 & 23,20 & 131,81 \\
\hline \multicolumn{9}{|c|}{ Corn } \\
\hline Grain & 50,20 & 45,10 & 64,40 & 47,90 & 64,10 & 61,60 & 57,10 & 113,74 \\
\hline Millet & 13,60 & 13,70 & 17,80 & 10,30 & 13,10 & 18,00 & 18,90 & 138,97 \\
\hline Buckwheat & 7,40 & 6,70 & 9,90 & 8,70 & 10,60 & 12,20 & 10,00 & 135,13 \\
\hline Fig & 58,30 & 50,50 & 57,30 & 62,10 & 60,00 & 50,00 & 53,40 & 91,59 \\
\hline Legumes & 17,50 & 15,10 & 14,60 & 15,60 & 14,50 & 21,40 & 20,40 & 116,57 \\
\hline \multicolumn{9}{|c|}{ Sugar beet } \\
\hline (Factory) & 315,00 & 279,00 & 363,00 & 411,00 & 399,00 & 477,00 & 436,00 & 138,41 \\
\hline Sunflower & 15,20 & 15,00 & 18,40 & 16,50 & 21,70 & 19,40 & 21,60 & 142,10 \\
\hline Rape & 18,50 & 17,00 & 17,30 & 22,00 & 23,60 & 25,40 & 25,90 & 140,00 \\
\hline Soy & 16,80 & 16,20 & 20,40 & 17,10 & 20,50 & 21,60 & 18,40 & 109,52 \\
\hline \multicolumn{9}{|c|}{ Flax } \\
\hline (Fibre) & 6,50 & 4,00 & 5,90 & 8,60 & 7,30 & 6,30 & 8,90 & 136,92 \\
\hline Potato & 139,00 & 132,00 & 168,00 & 161,00 & 160,00 & 176,00 & 161,00 & 115,82 \\
\hline Vegetables & 183,00 & 174,00 & 195,00 & 199,00 & 200,00 & 208,00 & 206,00 & 112,56 \\
\hline \multicolumn{9}{|c|}{ Annual grasses } \\
\hline Hay & 30,60 & 32,00 & 34,10 & 31,60 & 33,70 & 38,20 & 36,60 & 119,60 \\
\hline \multicolumn{9}{|c|}{ Perennial grasses } \\
\hline Hay & 32,20 & 35,80 & 38,00 & 36,50 & 38,30 & 45,70 & 38,10 & 136,92 \\
\hline Fruits and berries & 70,70 & 78,20 & 84,90 & 89,90 & 103,50 & 95,20 & 104,50 & 115,82 \\
\hline Grape & 66,00 & 60,30 & 75,50 & 67,20 & 85,80 & 98,60 & 92,30 & 112,56 \\
\hline
\end{tabular}


Table 4

Dynamics of acreage for major crops 2009-2015, ha

\begin{tabular}{|c|c|c|c|c|c|c|c|c|}
\hline Indicator & 2009 & 2010 & 2011 & 2012 & 2013 & 2014 & 2015 & Change, \% \\
\hline The entire cultivated area & 26990 & 26952 & 27670 & 27801 & 28329 & 27239 & 26902 & 99,67 \\
\hline Cereals & 15837 & 15090 & 15724 & 15449 & 16210 & 14801 & 14739 & 93,07 \\
\hline \multicolumn{9}{|c|}{ Including } \\
\hline Wheat & 6852 & 6451 & 6781 & 5772 & 6684 & 6061 & 6867 & 100,22 \\
\hline Rye & 468 & 286 & 284 & 303 & 284 & 187 & 152 & 32,48 \\
\hline Barley & 5122 & 4505 & 3787 & 3425 & 3359 & 3041 & 2826 & 55,17 \\
\hline Oat & 433 & 326 & 288 & 310 & 252 & 247 & 213 & 49,19 \\
\hline Maize & 2149 & 2709 & 3620 & 4625 & 4893 & 4691 & 4123 & 191,86 \\
\hline Millet & 119 & 95 & 169 & 191 & 98 & 103 & 112 & 94,12 \\
\hline Buckwheat & 273 & 225 & 311 & 300 & 189 & 140 & 133 & 48,72 \\
\hline Fig & 25 & 29 & 30 & 26 & 24 & 10 & 12 & 48,00 \\
\hline Legumes & 371 & 429 & 374 & 318 & 280 & 227 & 250 & 67,39 \\
\hline Industrial crops & 6545 & 7296 & 7441 & 7854 & 7869 & 8437 & 8350 & 127,58 \\
\hline \multicolumn{9}{|c|}{ Including } \\
\hline Sugar beet (factory) & 322 & 501 & 532 & 458 & 280 & 331 & 237 & 73,60 \\
\hline Sunflower & 4232 & 4572 & 4739 & 5194 & 5051 & 5257 & 5105 & 120,63 \\
\hline Rape & 1060 & 907 & 870 & 566 & 1017 & 882 & 682 & 64,34 \\
\hline Soy & 644 & 1076 & 1134 & 1476 & 1370 & 1806 & 2158 & 335,09 \\
\hline Flax & 2 & 1 & 2 & 2 & 2 & 2 & 2 & 100,00 \\
\hline Potatoes and cucurbit crops & 1950 & 1967 & 2028 & 2023 & 1961 & 1900 & 1823 & 93,49 \\
\hline Potato & 1409 & 1408 & 1439 & 1440 & 1388 & 1348 & 1291 & 91,63 \\
\hline Open ground vegetables (without seed) & 451 & 462 & 498 & 494 & 483 & 463 & 440 & 97,56 \\
\hline Forage crops & 2658 & 2599 & 2477 & 2475 & 2289 & 2101 & 1990 & 74,87 \\
\hline \multicolumn{9}{|c|}{ Including } \\
\hline $\begin{array}{l}\text { Fodder root crops (including sugar beet } \\
\text { to feed livestock) }\end{array}$ & 247 & 244 & 236 & 230 & 224 & 216 & 213 & 86,23 \\
\hline Annual grasses (including crops & 485 & 473 & 445 & 497 & 393 & 346 & 309 & 63,71 \\
\hline Corn for silage and green fodder & 585 & 583 & 531 & 499 & 469 & 408 & 393 & 67,18 \\
\hline $\begin{array}{l}\text { Grasses of previous years (mowed area } \\
\text { for coverless sowing) }\end{array}$ & 1289 & 1238 & 1207 & 1195 & 1152 & 1119 & 1027 & 79,67 \\
\hline Square pure vapour & 1523 & 1465 & 1211 & 1247 & 981 & 830 & 612 & 40,18 \\
\hline
\end{tabular}

negative changes in the structure of sown areas, because over the period decreased sown area of important crops such as potatoes, while an increase in sown area of sunflower - one of the most liquid cultures. This culture is very exhausting the soil and, therefore, the ten-course rotation should not take more than one field. However, in many cases, tenants grow on leased land only corn and sunflower and thereby destroy the fertile layer of soil, which is very difficult to recover (Sirenko, 2009).

Consequently, a significant increase in crop yields over the past year, the corresponding changes in the structure of sown areas led to a slight increase in the volume of gross crop production in 2015 compared to previous years.

The decline in production livestock industry is primarily due to significant changes that have occurred in the structure of livestock and poultry farms of all categories over the period.

The main reason for the decline of dairy and beef cattle farms in Ukraine are chronic loss-making industry because business owners reasonably rid of unprofitable enterprises - reduce the number of heads (Sirenko, 2009).
Renaissance of cattle is associated with significant investments, as most livestock buildings of the former collective and state farms are destroyed or redesigned. Moreover, in most cases, cultivated pastures become old shrubs.

The problems of the industry should note the low potential productivity of the existing number of cows, which need to improve dramatically selective stock breeding. It confronts business owners who wish to develop their farms' cattle in such financial constraints that they are not able to overcome (Andreychuk, 2015).

Thus, the decline in livestock production has become a macroeconomic factor since led to increased food shortages of animal origin, and thus to higher prices for them. This reinforced inflationary pressures, especially painful blow to the poorest segments of the population, to which such products have become available by the price.

For a comprehensive analysis of trends in agricultural development in Ukraine, there is required a detailed investigation of economic efficiency of all sectors of agricultural production. 
The worsening situation in agriculture is due not only to the lack of financial resources but also low-demand food and low purchasing power of the population.

The ban on exports to Russia also negatively affected the development of the industry, the result of which was a significant reduction in the production of milk and eggs.

Thus, among the main factors that, despite some improvements, restrain the growth of the industry and hamper the development of agricultural enterprises are the following (Pavlenko, 2015):

- failure and/or unavailability of financial resources;

- high fuel prices and seeds, deterioration of material base and, consequently, high production costs and low efficiency;

- mostly low yield production, which hinders its modernization and innovative development processes;

- the inconsistency of products with international quality standards and, therefore, low competitiveness in foreign markets;

- exports of raw materials and semi-finished products caused by the absence or the lack of capacity for effective processing and subsequent implementation;

- unstable political situation and military operations in the east, which caused a drop in production in the Donetsk and Luhansk regions and affected its reduction in Ukraine.

- towards sustainable rural development, a solution to the issues is possible through the implementation of sustainable economic, social, and environmental development, which can achieve the formation of clusters. "Economy of territories based on clusters - a model of an attractive and competitive economy based on the use of synergy effects and scale" (Andreychuk, 2015).

Clusters can cover all economic activities, including in the field of social service areas. In economically developed countries, clusters' formation is provided by the state support.

In Ukraine, the clusters are created spontaneously by "informal intuitive clustering" in agriculture, they took the form of food value chain, and their members are trying to get maximum benefit from the resources and are not intended to influence the development of rural areas. "Spontaneity and uncontrollability of such clusters are determined by the lack of clustering strategies in regional bodies that are responsible for balancing economic, social, and environmental components of sustainable development of territories under their jurisdiction" (Foreign direct investment in agriculture Ukraine declined by a third over the past year-UCAB, 2015).

Sugar beet processing system that existed in the prereform period can serve as examples of clusters. With the transition to a market economy, the country tried to get out of the strategies of regional cluster approach but the new owners of enterprises that process agricultural products have not yet reached an understanding of the need to act as integrators of respiratory congestion clusters.

However, in some regions, promoting the organization and functioning of clusters by public authorities have accumulated experience (e.g. Khmelnytskyi Regional State Administration initiated the creation of organic cluster systems). This work is also carried by Poltava Regional State Administration. But the factor that inhibits the clustering process is the lack of legal and regulatory framework and methodological support from the state and local governments, which can initiate the establishment of agro-industrial clusters to ensure a comprehensive rural development (Foreign direct investment in agriculture Ukraine declined by a third over the past year-UCAB, 2015).

An important condition for the agricultural development is the development of the field of logistics. Its basis - transportation and production operations, ensuring supply (procuring logistics), production (logistics) and marketing (distribution logistics) of agricultural products. The development of logistics around the capital city plays an important role in ensuring quality control of agricultural products and its direct supplies from the producer to the consumer without major metropolitan transport costs (Pavlenko, 2015).

The natural basis of agricultural area is favourable soil and climatic conditions. The presence of large amounts of black soil in southern areas and sod-podzolic soils in the northern areas, sufficient water availability in territories, and mostly favourable weather patterns create the necessary conditions for effective agriculture.

However, for increasing productivity, critical is not only the quality of soil and reclamation and appropriate measures and ensuring reasonable rotation. Land use restricted area because of their contamination. The accident at Chernobyl was removed with the use of 204 thousand hectares of Kyiv region, including 126 hectares of forest (Pavlenko, 2015).

The main areas of agricultural development, taking into account transformations in agriculture, are (Pavlenko, 2015):

- agriculture has developed on the basis of rational land use and ecosafety of land management to the needs of the capital city and in the food situation in domestic and international markets;

- efficient agriculture sectors of specialization field of economic and environmental positions can be grain crops (wheat, rye, and cereals), sugar beet, potatoes, vegetables, fruit and forage crops and cattle, poultry and pigs;

- over the environmental situation and the poor state of land resources, one should significantly reduce the share of sunflower crops as corn, soybeans, and canola, as well as to increase the role of natural pastures and perennial plants; 
- improving the efficiency of a typical suburban agriculture - horticulture, berry, potato, dairy and beef cattle, poultry - has come at the expense of intensification of production on the basis of innovation and investment;

- sugar beet is advisable to concentrate in areas with suitable natural conditions, and enhance the industry - through the introduction of modern technologies, mechanisms of economic stimulation of production and processing of sugar beet production;

- the best direction of livestock development should increase the productivity of livestock and poultry, improve product quality, intensify production;

- important is the creation of a modern infrastructure of the agrarian market development of logistics, creation of effective forms of production, promotion of a small business;

- an essential part of the further development of agricultural production in the region should be: job creation, increased employment in rural areas;

- all the areas of agricultural development in the context of the impact of the capital city are carried out taking maximum environmental factors into account.

\section{Findings}

Formation of a favourable investment climate, increased investment is a prerequisite for the gradual resumption of economic growth. So the investment public policy should be based on an integrated approach, combining mechanisms of the investment potential of the country, its regions, and sectors, especially agribusiness.

However, the process of increasing volumes of investments into the national economy inhibits a number of factors such as (Foreign direct investment in agriculture Ukraine declined by a third over the past year-UCAB, 2015):

- inconsistent investment policy in agriculture with a predominance of residual principles of budget funds and imperfect mechanisms of their use;

- innovative poor infrastructure, excessive wear, and lack of conditions for not only advanced but also a simple reproduction of fixed assets;

- processors' monopoly in agricultural markets and intermediaries, which leads to high transaction costs;

- low profitability of agricultural enterprises and hostile environment for small business in rural areas; - low liquidity of investments and the unresolved problem of mortgage;

- imperfect mechanism of economic relations between sectors, leading to low profitability and lack of capital investment attractiveness of the agricultural sector, which adversely affects the formation and expanded reproduction of material-technical base of agriculture.

The problem of providing investment industry is the acutest among small and medium-sized agricultural enterprises and private farms. Achieving improvements in this area are most dependent on the use of local opportunities for investment support. However, such opportunities in the most regions and areas are limited. Therefore, there becomes a problem of investment support for the development of agriculture and village scale. Solving it has a national significance and requires a consolidation of efforts of all levels and areas of production, society, government, and economic management. Scientists of NSC "Institute of Agrarian Economy" developed strategic directions of the development of agriculture of Ukraine until 2020, which defined a set of indicators that will contribute to the fully meeting the needs of agricultural development in investment capital (Foreign direct investment in agriculture Ukraine declined by a third over the past year-UCAB, 2015).

Economic and legal problems include (Foreign direct investment in agriculture Ukraine declined by a third over the past year-UCAB, 2015):

- gaps in the regulatory framework;

- high probability of political risk;

- a significant level of the shadow economy and corruption;

- the absence of economic, environmental, research, market, financial information, the streamlined marketing system of agricultural products;

- high level of risk for investors;

- low solvency of the population.

The financial and economic problems cover the lack of effective short-term and long-term lending industry and the low level of development of the leasing market.

Formation of a favourable investment climate in the market economy should be both at the macro and regional and sectoral levels through an objective assessment of existing problems, find ways to improve the situation and further optimization of the totality of political, legal, economic, social, organizational, informational factors.

To solve the problem of investment support for the agricultural development, envisaged (Foreign direct investment in agriculture Ukraine declined by a third over the past year-UCAB, 2015):

- the improvement of investment policy by reorienting it to stimulate investment entities, strengthening the role of investment support for agribusiness producers, and the improvement of the mechanisms of its implementation, improving conditions for attracting foreign investment in agricultural production and rural development;

- formation of investment resources in agriculture's proportions that characterize the relationship between own and borrowed sources as $2: 1$;

- improving the mechanisms of the state investment support for agricultural producers by providing it on a return basis, preventing cases of unjustified isolation and misuse of funds, refocusing support for the needs 
of small and medium businesses, increase in funding of investment in the development of the public sector in rural areas to the level of their needs;

- priority use of state budget funds for the development of seed-trial, tribal, education, irrigation water management, reforestation lands that are derived from the agricultural use, implementation of soil tillage systems with the contour of the territory;

- formation of a mechanism to support investments of private farms;

- creating conditions for the priority development of livestock, especially beef and dairy cattle from the state budget, loans, and equity investors;

- stabilizing and strengthening the role of credit facility during the formation of the sources of financing investment in agriculture;

- removing obstacles to foreign investors in agriculture in compliance with national interests;

- facilitate the creation of deserted rural areas separated farmers and tribal estates and their independent resources; - provision of depressed rural priority development status, which under the legislation provides incentives to investors;

- increased level of protection to investors and owners of land and property objects;

- directing at least a third of revenues to road funds to the construction, repair, and construction of roads in rural areas;

- implementation of measures to provide funding for the development of logistics research institutions of agribusiness in the amount of at least $6 \%$ of the value of their assets.

As this production is largely seasonal in nature, the proper functioning of the industry requires a rational and reasonable ratio between own and borrowed funds. Therefore, it increases the need to find external sources, the most common of which are loans.

\section{Conclusions}

Bank loans help to develop industry, small business, and agriculture but sustainable development needs primarily medium- and long-term loans. Short-term loans solve the problem of obtaining adequate resources for field work and long-term is a prerequisite for the expansion and renewal of assets.

A characteristic feature of the current state of lending to agricultural enterprises of Ukraine is the dominance of short-term loans. According to the International Finance Corporation, $77 \%$ of agricultural producers use the loans for the purchase of fuel and lubricants, $48 \%$ for the purchase of plant protection products, $36 \%$ - for the purchase of seed. Only $13 \%$ of companies use loans for the technological modernization of production and $6 \%$ - in its expansion (Foreign direct investment in agriculture Ukraine declined by a third over the past year-UCAB, 2015).

For the limited budgetary resources, it is necessary to cooperate with Ukrainian agricultural enterprises by foreign investors, which is investing in modernization of fixed assets. The equally important external source of financing of agricultural enterprises is foreign investments. But only $2 \%$ of total investments in Ukraine are directly invested in agriculture.

According to the Law of Ukraine "On State Support for Agriculture of Ukraine” budget support is provided to budgets of all levels in amounts, which prevent the normal working of unprofitable farms. As a result, it is concluded that the state support for agriculture - a complex of legislative and organizational budgetary measures that are objectively necessary to create a favourable competitive environment of the industry. These measures together with the criteria and conditions for their implementation form the mechanism of the state support of agriculture.

Summing up the above-mentioned, we can conclude that the relevant provisions for the development of agriculture of Ukraine are: state regulation, attractive investment climate, the use of ecological technology, the introduction of modern technologies, mechanisms of economic stimulation of production and processing of agricultural products. Cultures should be grown in a particular area given the climatic features that contribute to maximum productivity and profitability.

\section{References:}

Alex Pavlenko: Development of agriculture - the key to socio-economic and financial stability of our country [Electronic resource]. Available at: http://www.agroua.net/news/index.php? Nd = 20 \& monthsel = 04 \& yearsel $=2015$.

Andreychuk, V.G. (2015). The effectiveness of the agricultural enterprises: the theory, methodology, analysis: Monograph. K.: KNEU. - 290 p.

Foreign direct investment in agriculture Ukraine declined by a third over the past year-UCAB [Electronic resource]. Available at: http://www.agroua.net/news/index.php?nd=07\&monthsel $=04$ \& yearsel $=2015$.

Sirenko, N.M. (2009). The new role of agriculture in economic development. Visnik Bilotserkivskogo derzhavnogo agrarnogo universitetu. Vol 63. P. 58-61. 


\section{Светлана ХАЛАТУР}

\section{ВАЖНЫЕ РЕЗЕРВЫ РАЗВИТИЯ СЕЛЬСКОГО ХОЗЯЙСТВА УКРАИНЫ}

Аннотация. Целью работы является изучение состояния развития сельского хозяйства Украины. Проанализированы показатели производства и урожайности основных сельскохозяйственных культур и производства основных видов продукции животноводства. Определены основные направления развития сельского хозяйства с учетом трансформаций в аграрной сфере. Исследованы решения проблемы инвестиционного обеспечения развития сельского хозяйства. Приведены основные факторы, которые сдерживают рост отрасли и тормозят развитие сельскохозяйственных предприятий. По результатам анализа определены основные проблемы, с которыми в последнее время сталкивается отрасль, и приведены вопросы, требующие первоочередного решения. Предметом являются теоретико-методологические основы и практические рекомендации по поводу поиска резервов развития отрасли сельского хозяйства. Методика. Исследование основано на сравнении данных с 2009 по 2015 года, используя статистические сборники. Результаты исследования показали, что отрасль животноводства начинает сокращаться в Украине и это означает, что при дальнейшей такой ситуации, возможно потерять возможность не только экспортировать животноводческую продукцию за границу, но и обеспечивать внутренние потребности населения страны. Рассмотрено состояние сельского хозяйства Украины. Результаты показали, что основными резервами развития сельского хозяйства Украины является государственное регулирование, оценка привлекательности инвестиционного климата, использование экологически безопасных технологий, использование современных технологий и механизмов экономического стимулирования производства и переработки сельскохозяйственной продукции. Значение/оригинальность. Полученные данные за исследуемые года основных резервов развития сельского хозяйства Украины способны обеспечить лучшее понимание состояния отрасли сельского хозяйства в условиях экономического спада в целом и в Литве, в частности. 